\title{
ZASTOSOWANIE FUNKCJI WEIBULLA DO OCENY WYTRZYMALOŚCI NA ROZCIĄGANIE KORZENI WYBRANYCH GATUNKÓW DRZEW
}

\author{
Tymoteusz Zydroń, Andrzej Gruchot ${ }^{凶}$, Kamil Czesak \\ Wydział Inżynierii Środowiska i Geodezji, Uniwersytet Rolniczy w Krakowie, Kraków
}

\begin{abstract}
STRESZCZENIE
Celem pracy było określenie wytrzymałości na rozciaganie korzeni brzozy brodawkowatej, grabu pospolitego i sosny zwyczajnej oraz wartości parametrów funkcji Weibulla $(\omega, \lambda)$ opisujących zmienność tej charakterystyki. Wyniki badań wytrzymałości na rozciaganie oraz wartości parametrów funkcji Weibulla zastosowano do określenia wartości przyrostu wytrzymałości na ścinanie gruntu wzmocnionego korzeniami za pomocą klasycznego modelu Wu-Waldrona (W-W) oraz odkształceniowego modelu wiązkowego (FBMw).

Wyniki badań wykazały, że korzenie grabu zwyczajnego charakteryzują się statystycznie istotnie większą wytrzymałością na rozciagganie niż korzenie brzozy brodawkowatej i sosny zwyczajnej. Stwierdzono, że wartości parametrów funkcji Weibulla były niewielkie, a wartości parametru $\omega$ wskazują na dużą zmienność charakterystyki wytrzymałościowej korzeni badanych gatunków drzew. Wykazano, że dobór parametrów funkcji Weibulla ma nieznaczny wpływ na obliczenia przyrostu wytrzymałości na ścinanie gruntu wzmocnionego korzeniami. Uzyskane wartości tego parametru z użyciem modelu wiązkowego wykorzystującego funkcję przeżywalności Weibulla (FBMw) były od 47 do 59\% mniejsze w stosunku do klasycznego model Wu-Waldrona (W-W).
\end{abstract}

Słowa kluczowe: wytrzymałość na rozciaganie korzeni, wzmocnienie gruntu korzeniami, funkcja Weibulla, model wiązkowy

\section{WSTĘP}

Interakcja systemów korzeniowych roślin z gruntem jest jednym z głównych czynników ich oddziaływania na stateczność zboczy. Duża bioróżnorodność roślin oraz wiele czynników powodują dużą zmienność architektury systemów korzeniowych (Mattia, Bischetti i Gentile, 2005; Stokes, Atger, Bengough, Fourcaud i Sidle, 2009), a tym samym powoduja, że ich wpływ na wzmocnienie gruntu jest bardzo zróżnicowany, nawet w obrębie jednego gatunku (Vergani, Schwarz, Cohen, Thormann \& Bischetii, 2014). Generalnie uznaje się, że wpływ ten związany jest z liczbą korzeni (gęstością systemu korzeniowego) oraz ich wytrzymałością na rozciaganie.
Metody obliczeniowe stosowane do określenia efektu wzmocnienia gruntu przez systemy korzeniowe zakładają, że właściwości wytrzymałościowe korzeni są silnie związane $\mathrm{z}$ ich średnica, a pomijają dużą zmienność obydwu tych parametrów (Loades, Bengough, Bransby i Hallett, 2010; Schwarz, Giadrossich i Cohen, 2013). Schwarz, Giadrossich i Cohen (2013) zaproponowali zastosowanie rozkładu Weibulla do opisu przyrostu wytrzymałości na rozciąganie korzeni (model RBMw), wykazując, że zastosowanie takiego podejścia pozwala dobrze odwzorować wyniki badań terenowych. Stąd też w ostatnich latach model ten znajduje coraz szersze zastosowanie w badaniach dotyczacych problematyki wzmacniania zboczy przez systemy korzeniowe roślin (Vergani i in., 2014;

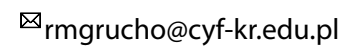


Zydroń, T., Gruchot, A., Czesak, K. (2018). Zastosowanie funkcji Weibulla do oceny wytrzymałości na rozciąganie korzeni wybranych gatunków drzew. Acta Sci. Pol. Architectura, 17 (4), 61-69. doi: 10.22630/ASPA.2018.17.4.41

Vergani i in., 2016; Giadrossich i in., 2016; Cislaghi, Bordoni, Meisina i Bischetti, 2017; Vergani, Werlen, Conedera, Cohen i Schwarz, 2017). Jak podkreślają autorzy modelu niezbędne są jednak dalsze prace, które dostarczą dane do jego kalibracji i walidacji.

Celem pracy było określenie wytrzymałości na rozciaganie korzeni brzozy brodawkowatej, grabu pospolitego i sosny zwyczajnej oraz określenie wartości parametrów funkcji przeżywalności Weibulla charakteryzujących tę cechę. Wybór gatunków roślin związany jest $\mathrm{z}$ ich stosunkowo dużym rozpowszechnieniem na terenie naszego kraju, a także praktycznie brakiem danych dotyczącym właściwości wytrzymałościowych ich korzeni. Na podstawie wyników badań, stosując model wiązkowy wykorzystujący wartości funkcję przeżywalności Weibulla, obliczono przyrost wytrzymałości na ścinanie gruntu wzmocnionego korzenia$\mathrm{mi}$, a jej wartości porównano $\mathrm{z}$ wynikami obliczeń z wykorzystaniem klasycznego modelu Wu-Waldrona (W-W) (Wu, 1976; Waldron, 1977).

\section{ZAKRES I METODY}

Próbki korzeni do badań wytrzymałości na rozciaganie badanych gatunków drzew pochodziły $\mathrm{z}$ okolic Bochni (województwo małopolskie). Próbki o długości co najmniej $0,2 \mathrm{~m}$ bezpośrednio przed badaniem wytrzymałości na rozciąganie zostały umieszczone w wodzie na $24 \mathrm{~h} \mathrm{w}$ celu ich nasycenia. Badania prowadzono w zrywarce Hounsfield H50KS przy prędkości odkształcenia $10 \mathrm{~mm} \cdot \mathrm{min}^{-1}$ do momentu zerwania lub wysunięcia się próbki korzenia ze szczęk urządzenia. Do dalszej analizy uwzględniono tylko te próbki korzeni, które uległy zerwaniu, mierząc ich średnice w tym miejscu. Analiza statystyczna wyników badań polegała na porównaniu wartości siły zrywającej pomiędzy badanymi gatunkami. W tym celu wykonano analizę kowariancji (ANCOVA) na poziomie istotności 0,01 , w której zmienną zależną była wartość siły zrywającej, a zmienną towarzyszącą średnica korzeni.

Na podstawie uzyskanych wyników badań określono zależność siły zrywającej od ich średnic, zakładając przekrój kołowy korzeni. Na podstawie wielkości odkształcenia próbki w momencie zerwania określono moduł odkształcenia. Wyniki te wykorzystano do określenia przyrostu wytrzymałości na ścinanie zwią- zanej z obecnością korzeni w gruncie. W tym celu wykorzystano model Wu-Waldrona (Wu, 1976; Waldron, 1977) oraz model wiązkowy uwzględniający wielkość siły rozciagającej przenoszonej przez korzenie jako zmienną zależną od ich odkształcenia oraz prawdopodobieństwa jego zniszczenia (zerwania) (Schwarz $\mathrm{i}$ in., 2013).

W modelu Wu-Waldrona (W-W) przyjmuje się, że $\mathrm{w}$ trakcie ścinania gruntu równocześnie we wszystkich korzeniach jest mobilizowana maksymalna siła rozciagająca. Wartość przyrostu wytrzymałości na ścinanie oblicza się z zależności:

$$
c_{R}=k^{\prime} \cdot \sum_{i=1}^{N} T_{R i} \cdot\left(R A R_{i}\right)
$$

gdzie:

$k^{\prime} \quad$ - współczynnik orientacji korzeni (zazwyczaj $1,0-1,3)$, w obliczeniach przyjęto $k^{\prime}=1,0$,

$T_{R i}$ - wytrzymałość na rozciaganie korzenia o średnicy $d_{i}$,

$R A R_{i}$ - względna powierzchnia korzenia o średnicy $d_{i} \mathrm{w}$ gruncie w rozpatrywanym przekroju.

Zastosowanie zależności (1) prowadzi zwykle do przeszacowania wartości przyrostu wytrzymałości na ścinanie gruntu zbrojonego korzeniami (Pollen-Bankhead \& Simon, 2009; Schwarz, Giadrossich i Cohen, 2013; Zydroń, 2014). Coraz częściej do opisu wpływu korzeni na grunt wykorzystuje się więc różne odmiany modeli wiązkowych (Fiber Bundle Model) zakładające progresywny sposób przekazywania sił rozciagających na system korzeniowy (Pollen-Bankhead \& Simon, 2005; Hales, Ford, Hwang, Vose \& Band, 2009; Mao i in., 2012). Schwarz, Thormann, Zürcher \& Feller (2012) zaproponowali odkształceniowy model wiązkowy, w którym podstawowe zależności pomiędzy parametrami geometrycznymi korzeni oraz wartościami mobilizowanej siły zrywającej oraz odkształceniem korzeni opisane są następującymi zależnościami:

$$
\begin{gathered}
L\left(d_{i}\right)=L_{0} \cdot\left(\frac{d_{i}}{d_{0}}\right)^{\gamma} \\
E\left(d_{i}\right)=E_{0} \cdot\left(\frac{d_{i}}{d_{0}}\right)^{\beta} \cdot r
\end{gathered}
$$




$$
F_{\text {max }}\left(d_{i}\right)=F_{0} \cdot\left(\frac{d_{i}}{d_{0}}\right)^{\xi}
$$

gdzie:

$$
\begin{aligned}
& L\left(d_{i}\right) \quad \text { - długość korzenia o średnicy , } d_{i} \text { ”, } \\
& L_{0} \quad \text { - empiryczna charakterystyczna długość ko- } \\
& \text { rzenia o średnicy } d_{0} \text {, } \\
& \gamma, \xi, \beta \text { - wykładnik potęgowy, } \\
& d_{0} \quad \text { - średnica charakterystycznego korzenia }
\end{aligned}
$$

Rozwijając model obliczeniowy Schwarz $\mathrm{i}$ in. (2013), uwzględnili to, że wartość siły zrywającej w poszczególnych korzeniach może charakteryzować się zmiennością i w związku z tym do określenia wielkości siły przenoszonej przez system korzeniowy zastosowali funkcję przeżywalności Weibulla:

$$
F_{\text {total }}(\Delta x)=\sum_{i-1}^{N} F\left(d_{i}, \Delta x_{i}\right) \cdot S\left(\Delta x_{i}^{*}\right)
$$

gdzie:

$S\left(\Delta x_{i}^{*}\right)-$ dwuparametryczna funkcja przeżywalno-

$$
S\left(\Delta x_{i}^{*}\right)=\exp \left[-\left(\frac{\Delta x^{*}}{\lambda}\right)^{\omega}\right]
$$

gdzie:

$\omega \quad-$ współczynnik kształtu funkcji Weibulla,

$\lambda \quad-$ parametr skali,

$\Delta x^{*} \quad-$ znormalizowane odkształcenie korzenia o średnicy , $d_{i}$ " obliczane jako iloraz wielkości odkształcenia $\mathrm{w}$ momencie jego zerwania uzyskanej z badań do teoretycznej wielkości tego parametru,

$F\left(d_{i}, \Delta x_{i}\right)$ - wartość siły rozciagające korzenia o średnicy , $d_{i}$ " przy odkształceniu $\Delta x$.

Po odniesieniu wartości siły rozciagającej (5) do powierzchni przekroju gruntu można obliczyć wartość przyrostu wytrzymałości na ścinanie.

W części analitycznej dla 4 założonych schematów dystrybucji systemów korzeniowych w gruncie - RD (rys. 1) obliczono przyrost wytrzymałości na ścinanie gruntu z zastosowaniem klasycznego modelu Wu-Waldrona (Wu, 1976; Waldron, 1977). W obliczeniach przyjęto, że powierzchnia względna korzeni wynosi $R A R_{i}=0,2 \%$, co jest zbliżone do średniej wartości tego parametru dla systemów korzeniowych gatunków drzew występujących na terenach górzystych Europy (Bischetti i in., 2005; Bischetti, Chiaradia, Epis \& Morlotti, 2009; Vergani i in., 2014).

Następnie dla wyżej założonych schematów dystrybucji systemu korzeniowego wykonano obliczenia przyrostu wytrzymałości na ścinanie, stosując model wiązkowy, w którym wielkość siły rozciągającej korzeni była zmienną zależną od ich odkształcenia (Schwarz i in., 2013). W tym celu określono wartości parametrów $(\omega, \lambda)$ funkcji przeżywalności Weibulla, które ustalono zgodnie z procedurą podaną przez Schwarza i in. (2013). Na potrzeby niniejszej pracy w przypadku każdego gatunku drzewa parametry $\omega$ i $\lambda$ zostały określone $\mathrm{w}$ odniesieniu do całego zakresu badanych średnic korzeni i pewnych ich przedziałów, przyjmując trzy warianty obliczeń:

1) FBM-v1 - taka sama para wartości parametrów $\omega$ i $\lambda$ dla wszystkich średnic korzeni - $(0-5) \mathrm{mm}$,

2) FBM-v2 - wartości parametrów $\omega$ i $\lambda$ określono dla następujących przedziałów średnic korzeni:

- dla brzozy brodawkowatej i sosny zwyczajnej: $(0-2) \mathrm{mm}$ i $\langle 2-5) \mathrm{mm}$,

- dla grabu pospolitego: $(0-2) \mathrm{mm},\langle 2-3) \mathrm{mm}$ $\mathrm{i}\langle 3-5) \mathrm{mm}$,

3) FBM-v3 - wartości parametrów $\omega$ i $\lambda$ określono dla następujących przedziałów średnic korzeni:

- dla brzozy brodawkowatej i sosny zwyczajnej: $(0-1,5) \mathrm{mm},\langle 1,5-2,5) \mathrm{mm}$ oraz $\langle 2,5-5) \mathrm{mm}$,

- dla grabu pospolitego: $(0-1,5) \mathrm{mm},\langle 1,5-2,5)$ $\mathrm{mm},\langle 2,5-3,5) \mathrm{mm}$ oraz $\langle 3,5-5,0) \mathrm{mm}$. 
Zydroń, T., Gruchot, A., Czesak, K. (2018). Zastosowanie funkcji Weibulla do oceny wytrzymałości na rozciąganie korzeni wybranych gatunków drzew. Acta Sci. Pol. Architectura, 17 (4), 61-69. doi: 10.22630/ASPA.2018.17.4.41

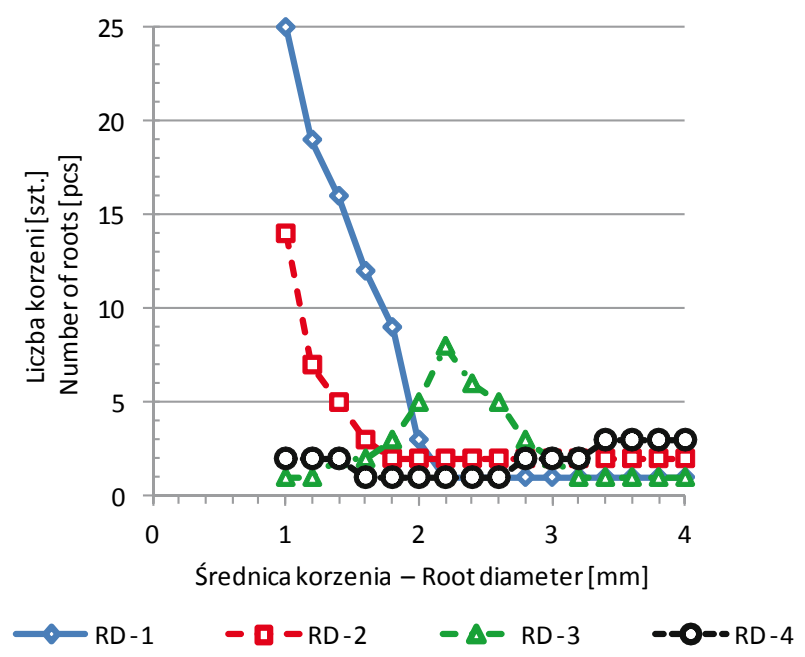

Rys. 1. Założone schematy dystrybucji systemu korzeniowego (RD) w gruncie w obliczeniach przyrostu wytrzymałości na ścinanie

Fig. 1. Root distribution variants (RD) used for calculation of root cohesion

Przyjęty przedział średnic korzeni wynikał z ilości danych pomiarowych. Przyjęto, że minimalna liczba pomiarów służących do określeniu wartości parametrów $\omega$ i $\lambda$ powinna wynosić 10 , a dobór wartości parametrów funkcji Weibulla miał wykazać wrażliwość zastosowanego modelu wiązkowego na dane wejściowe.

\section{WYNIKI I ICH ANALIZA}

Na rysunku 2 przedstawiono wyniki wytrzymałości na rozciaganie korzeni badanych gatunków drzew. Stwierdzono, że wytrzymałość na rozciaganie korzeni grabu pospolitego pod względem statystycznym była istotnie większa niż wytrzymałość korzeni brzozy a) brzoza brodawkowata - Common birch

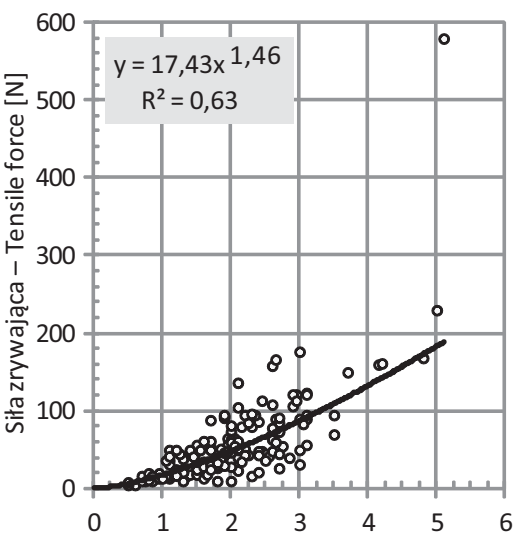

Średnica korzenia - Root diameter [mm] b) grab pospolity - European hornbeam

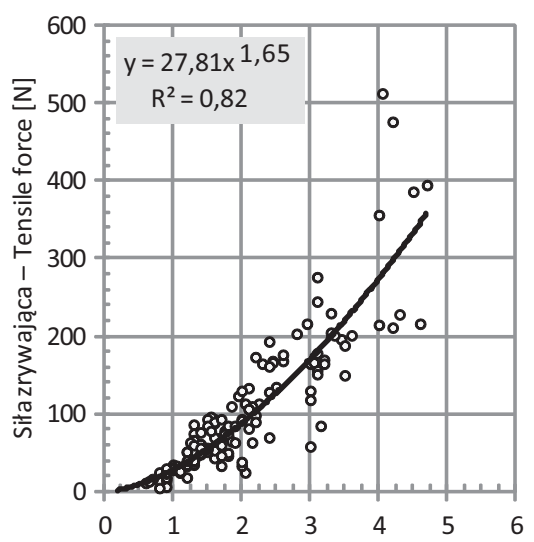

Średnica korzenia - Root diameter [mm] c) sosna zwyczajna - Scots pine

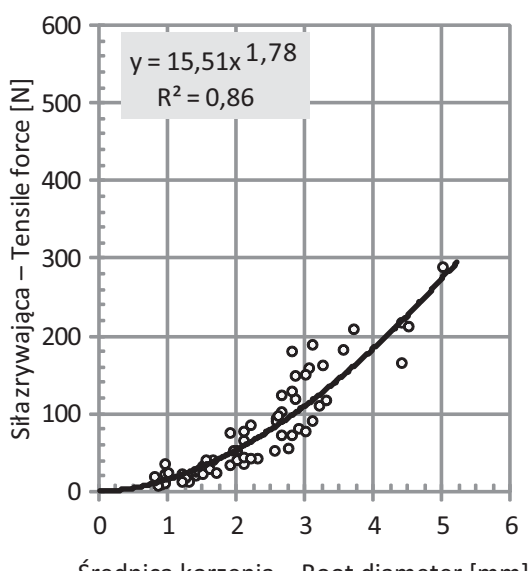

Rys. 2. Zależność siły zrywającej od średnicy korzeni

Fig. 2. Tensile force vs. root diameter 
Zydroń, T., Gruchot, A., Czesak, K. (2018). Zastosowanie funkcji Weibulla do oceny wytrzymałości na rozciąganie korzeni wybranych gatunków drzew. Acta Sci. Pol. Architectura, 17 (4), 61-69. doi: 10.22630/ASPA.2018.17.4.41

brodawkowatej i sosny zwyczajnej. Z kolei wytrzymałość na zrywanie korzeni brzozy brodawkowatej i sosny zwyczajnej nie różniła się istotnie na poziomie ufności $0,01(\mathrm{p}=0,12)$. Z uzyskanych danych wynika również, że pomimo stosunkowo wysokich wartości współczynnika determinacji wartości siły zrywającej różnią się istotnie od wyznaczonej linii trendu.

$\mathrm{W}$ tabeli zestawione wyniki obliczeń parametrów $\omega$ i $\lambda$ korzeni każdego $z$ analizowanych gatunków drzew dla 3 wariantów obliczeń. Na rysunku 3 przedstawiono przykładowo dla korzeni brzozy brodawkowatej wyniki dopasowania parametrów $\omega$ i $\lambda$ określone dla różnych przedziałów ich średnic.

Zakres wartości parametru skali $\lambda$ i wskaźnika kształtu $\omega \mathrm{w}$ funkcji przeżywalności Weibulla był różny w zależności od gatunku drzewa oraz przyjętego wariantu obliczeniowego i przedziału średnicy korzeni. Uzyskane wyniki wskazują na dużą zmienność charakterystyki wytrzymałościowej korzeni badanych gatunków drzew.

W wariancie obliczeniowym FBM-v1 zakres wartości parametru $\lambda$ był najmniejszy i mieścił się w zakresie od 1,12 do 1,17 dla wszystkich gatunków drzew. W wariancie FBM-v2 jego zakres wahał się od 1,10 do 1,16 dla brzozy brodawkowatej i sosny zwyczajnej oraz od 0,95 do 1,23 dla grabu pospolitego. $\mathrm{W}$ przypadku wariantu FBM-v3 uzyskano największy zakres wartości parametru $\lambda$, który wynosił od 0,85 do 1,43 dla brzozy brodawkowatej i sosny zwyczajnej oraz do 1,05 do 1,27 dla grabu pospolitego. Ogólnie można stwierdzić, że uzyskane wartości tego parametru były zbliżone do wyników estymacji tego parametru podanych w pracy Schwarza i in. (2013).

Wartości parametru $\omega$, a także jego zakres był znacznie większy niż parametru $\lambda$ i zasadniczo mieściły się w przedziale od 2,6 do 4,5 , co również odpowiada zakresowi podanym przez Schwarza i in. (2013), Giadrossicha i in. (2016), Vergani i in. (2014, 2016), Vergani, Werlena, Conederę, Cohena i Schwarza (2017) i Cislaghiego i in. (2017). Jedynie w przypadku wariantu FBM-v3 i zakresu średnic $\langle 2,5-5) \mathrm{mm}$ parametr ten wynosił 15 , co wynikało $z$ małej liczby danych w tym przedziale średnic. Najwyższe wartości tego parametru uzyskano dla korzeni grabu pospolitego, a najniższe dla sosny zwyczajnej, które wynosily odpowiednio od 3,5 do 4,5 oraz od 2,6 do 3,0. Należy również nadmienić, że średnie wartości obydwu parametrów przeżywalności funkcji Weibulla uzyskane w wariancie FBM-v2 i FBM-v3 były bardzo bliskie wartościom określonym w wariancie FBM-v1.

Tabela. Wartości parametrów funkcji przeżywalności Weibulla badanych gatunków drzew

Table. Value of parameters of Weibull survival function determined for tested tree species

\begin{tabular}{|c|c|c|c|c|c|c|c|}
\hline \multirow{2}{*}{$\begin{array}{l}\text { Wariant obliczeniowy } \\
\text { Calculation variant }\end{array}$} & \multirow{2}{*}{$\begin{array}{c}\text { Przedział średnic } \\
\text { korzeni } \\
\text { Range of root diameters } \\
{[\mathrm{mm}]}\end{array}$} & \multicolumn{2}{|c|}{$\begin{array}{l}\text { Brzoza brodawkowata } \\
\text { Common birch }\end{array}$} & \multicolumn{2}{|c|}{$\begin{array}{c}\text { Grab pospolity } \\
\text { European hornbeam }\end{array}$} & \multicolumn{2}{|c|}{$\begin{array}{c}\text { Sosna zwyczajna } \\
\text { Scots pine }\end{array}$} \\
\hline & & $\lambda[-]$ & $\omega[-]$ & $\lambda[-]$ & $\omega[-]$ & $\lambda[-]$ & $\omega[-]$ \\
\hline FBM-v1 & $(0-5)$ & 1,13 & 3,16 & 1,12 & 4,01 & 1,17 & 2,82 \\
\hline \multirow{4}{*}{ FBM-v2 } & $\langle 0-2)$ & 1,15 & 2,94 & 1,13 & 4,48 & 1,16 & 2,81 \\
\hline & $\langle 2-3)$ & \multirow{2}{*}{1,10} & \multirow{2}{*}{3,48} & 0,95 & 4,30 & \multirow{2}{*}{1,14} & \multirow{2}{*}{2,84} \\
\hline & $\langle 3-5)$ & & & 1,23 & 3,66 & & \\
\hline & średnia & 1,13 & 3,21 & 1,10 & 4,15 & 1,15 & 2,83 \\
\hline \multirow{5}{*}{ FBM-v3 } & $\langle 0-1,5)$ & 1,02 & 3,48 & 1,16 & 4,40 & 1,11 & 2,59 \\
\hline & $\langle 1,5-2,5)$ & 1,23 & 3,26 & 1,05 & 3,93 & 1,43 & 2,97 \\
\hline & $\langle 2,5-3,5)$ & \multirow{2}{*}{0,93} & \multirow{2}{*}{3,63} & 1,08 & 3,51 & \multirow{2}{*}{0,85} & \multirow{2}{*}{15,0} \\
\hline & $\langle 3,5-5)$ & & & 1,27 & 4,28 & & \\
\hline & średnia & 1,06 & 3,46 & 1,14 & 4,03 & 1,13 & 6,85 \\
\hline
\end{tabular}


a) FBM-v1, (0-5) $\mathrm{mm}$

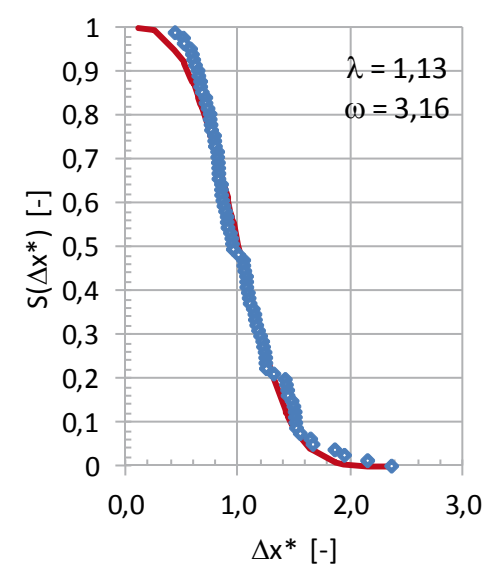

d) FBM-v3, $\langle 0-1,5) \mathrm{mm}$

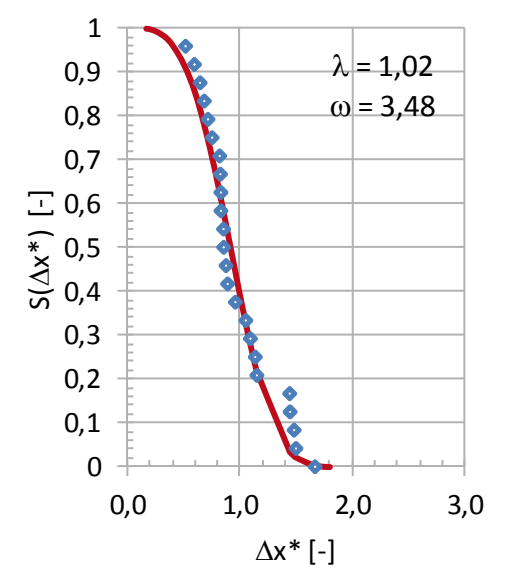

b) FBM-v2, $(0-2) \mathrm{mm}$

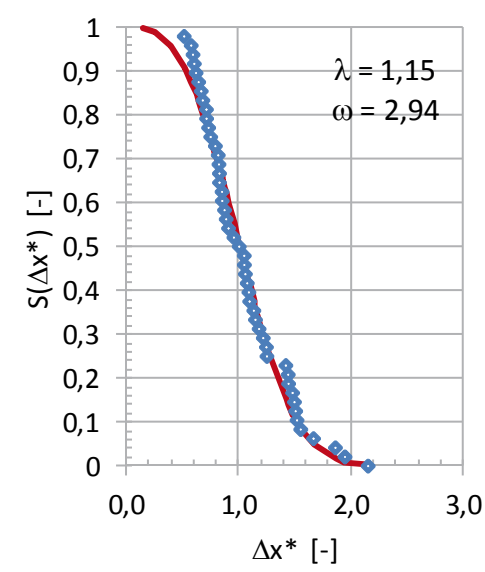

e) FBM-v3, $\langle 1,5-2,5) \mathrm{mm}$

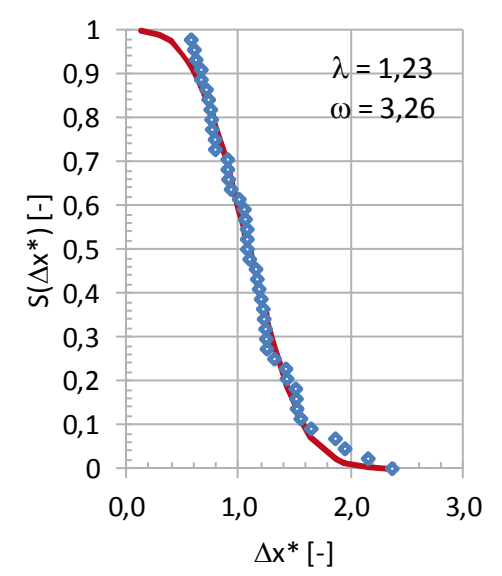

c) FBM-v2, $(2-5) \mathrm{mm}$

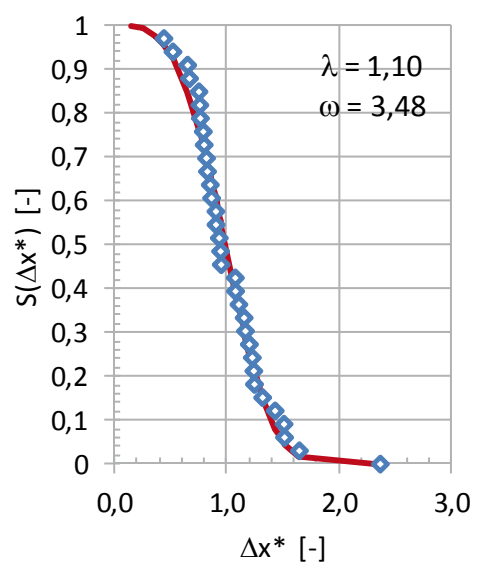

f) FBM-v3, $\langle 2,5-5,0) \mathrm{mm}$

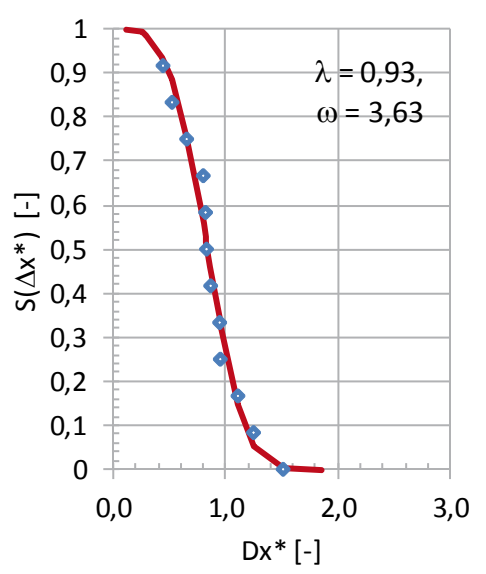

- wynikibadań-measured data

funkcja przeżywalności - survival function

Rys. 3. Wartości funkcji dopasowania określone dla różnych przedziałów średnic korzeni brzozy brodawkowatej

Fig. 3. Survival function calculated for different root diameter classes determined for common birch

Dla określenia wrażliwości modelu wiązkowego na dane wejściowe, w postaci różnych wartości parametrów przeżywalności funkcji Weibulla, obliczono wartości przyrostu wytrzymałości na ścinanie (rys. 4) i porównano je z wynikami obliczeń za pomocą modelu Wu-Waldrona (W-W). Poniżej przedstawiono analizę wartości przyrostu wytrzymałości na ścinanie $\mathrm{z}$ obydwu modeli obliczeniowych dla przyjętych 4 schematów dystrybucji korzeni i 3 wariantów obliczeń parametrów funkcji przeżywalności Weibulla dla badanych gatunków drzew.

1. Dla brzozy brodawkowatej stwierdzono, że:
- wartości przyrostu wytrzymałości na ścinanie gruntu uzyskane z modelu $\mathrm{W}-\mathrm{W}$ wahały się od 24 do $32 \mathrm{kPa}$, a z modelu wiązkowego od 11 do $16 \mathrm{kPa}$ dla wszystkich 4 schematów dystrybucji systemów korzeniowych. Wskazuje to na co najmniej 2-krotną różnicę $\mathrm{w}$ wartości przyrostu wytrzymałości na ścinanie,

- zmiany przyrostu wytrzymałości na ścinanie pomiędzy wariantami obliczeniowymi parametrów przeżywalności $\mathrm{w}$ modelu wiązkowym dla poszczególnych schematów dystrybucji korzeni wynosiły od 0,2 do $1,2 \mathrm{kPa}$ (1 do $11 \%$ względne), 
Zydroń, T., Gruchot, A., Czesak, K. (2018). Zastosowanie funkcji Weibulla do oceny wytrzymałości na rozciąganie korzeni wybranych gatunków drzew. Acta Sci. Pol. Architectura, 17 (4), 61-69. doi: 10.22630/ASPA.2018.17.4.41

a) brzoza brodawkowata - common birch

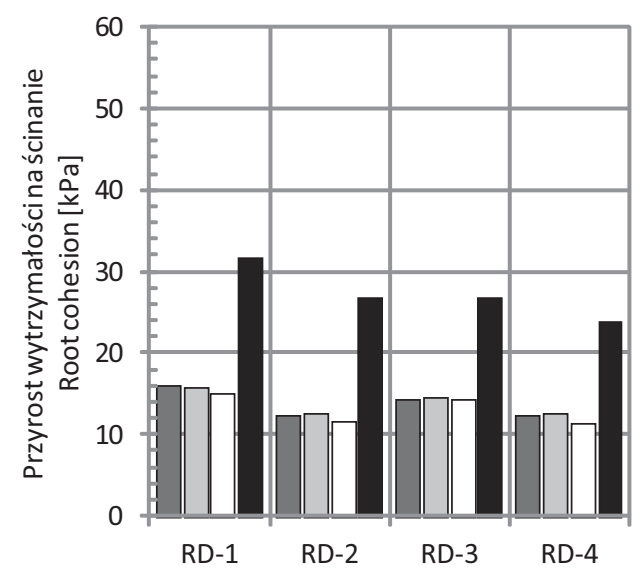

Wariant dystrybucji systemu korzeniowego Variant of root distribution

c) sosna zwyczajna - Scots pine

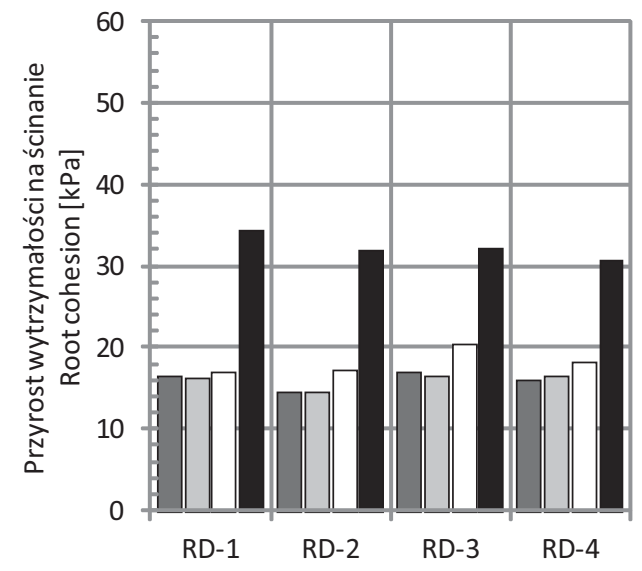

Wariant dystrybucji systemu korzeniowego Variant of root distribution b) grab pospolity - European hornbeam

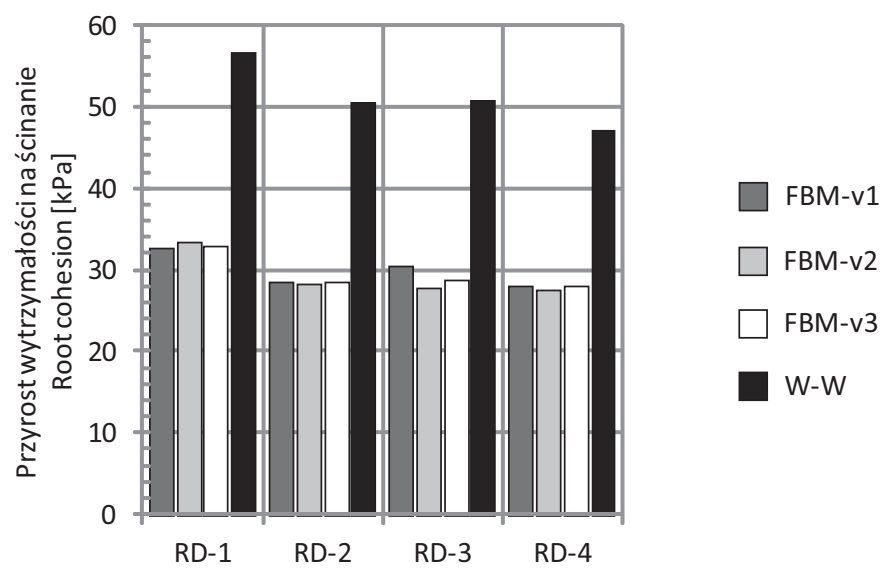

Wariant dystrybucjisystemu korzeniowego Variant of root distribution

Rys. 4. Wartości przyrostu wytrzymałości na ścinanie gruntu zbrojonego korzeniami obliczone za pomocą modelu Wu-Waldrona (W-W) i wiązkowego z uwzględnieniem wariantów obliczeń parametrów funkcji przeżywalności Weibulla (FBM-v1, FBM-v2, FBM-v3) dla 4 założonych schematów dystrybucji systemów korzeniowych (RD-1-RD-4)

Fig. 4. Root cohesion values estimated by Wu-Waldron model (W-W) and fiber bundle model using Weibull survival function (FBM-v1, FBM-v2, FBM-v3) for 4 variant of root distribution (RD-1-RD-4)

- różnice w przyroście wytrzymałości na ścinanie pomiędzy schematami dystrybucji korzenia dla poszczególnych wariantów obliczeń parametrów przeżywalności wahały się od 3,3 do $3,8 \mathrm{kPa}$ (26 do 34\% względne).

2. Dla grabu pospolitego stwierdzono, że:

- wartości przyrostu wytrzymałości na ścinanie gruntu uzyskane $\mathrm{z}$ modelu $\mathrm{W}-\mathrm{W}$ wahały się od 45 do $57 \mathrm{kPa}$, a z modelu wiązkowego od 28 do $34 \mathrm{kPa}$ dla wszystkich 4 schematów dystrybucji systemów korzeniowych. Wskazuje to na średnio $70 \%$ różnicę $\mathrm{w}$ wartości przyrostu wytrzymałości na ścinanie,

- zmiany przyrostu wytrzymałości na ścinanie pomiędzy wariantami obliczeniowymi parametrów przeżywalności w modelu wiązkowym dla poszczególnych schematów dystrybucji korzeni wynosiły od 0,4 do $2,7 \mathrm{kPa}$ (1 do 10\% względne),

- różnice w przyroście wytrzymałości na ścinanie pomiędzy schematami dystrybucji korzenia dla poszczególnych wariantów obliczeń parametrów przeżywalności wahały się od 4,7 do $5,9 \mathrm{kPa}$ (17 do 21\% względne).

3. Dla sosny zwyczajnej stwierdzono, że:

- wartości przyrostu wytrzymałości na ścinanie gruntu uzyskane $\mathrm{z}$ modelu $\mathrm{W}-\mathrm{W}$ wahały się od 
31 do $35 \mathrm{kPa}$, a $\mathrm{z}$ modelu wiązkowego od 14 do $20 \mathrm{kPa}$ dla wszystkich 4 schematów dystrybucji systemów korzeniowych, a więc z modelu W-W uzyskano od 1,6- do 2,1-krotnie wyższą jej wartość,

- zmiany przyrostu wytrzymałości na ścinanie pomiędzy wariantami obliczeniowymi parametrów przeżywalności w modelu wiązkowym dla poszczególnych schematów dystrybucji korzeni wynosiły od 0,7 do $3,7 \mathrm{kPa}$ (4 do $22 \%$ względne),

- różnice w przyroście wytrzymałości na ścinanie pomiędzy schematami dystrybucji korzenia dla poszczególnych wariantów obliczeń parametrów przeżywalności wahały się od 2,2 do $3,4 \mathrm{kPa}$ (15 do $20 \%$ względne).

Przedstawiona powyżej analiza wskazuje, że zastosowanie modelu Wu-Waldrona $(\mathrm{W}-\mathrm{W})$ pozwala uzyskać znacznie wyższe wartości przyrostu wytrzymałości na ścinanie gruntów wzmocnionych korzeniami w stosunku do wyników badań uzyskiwanych z modelu wiązkowego. Stosujac model wiązkowy, uzyskano od 47 do $59 \%$ mniejsze wartości przyrostu wytrzymałości na ścinanie gruntu wzmocnionego korzeniami w stosunku do modelu W-W, co mieściło się w zakresie różnic podawanych w literaturze (Pollen-Bankhead \& Simon, 2005; Bischetti i in., 2009; Schwarz i in., 2013). Najmniejsze różnice wyników obliczeń obydwoma modelami (średnio o 42\%) uzyskano w przypadku grabu pospolitego, co było związane ze stosunkowo wysoką wartością parametru $\omega$ (około 4,0). Otrzymane zależności pomiędzy wynikami obliczeń przyrostu wytrzymałości na ścinanie modelem Wu-Waldrona i wiązkowym są bardzo zbieżne z wynikami badań Bischettiego i in. (2009), którzy wskazują, że wartości analizowanego parametru można oszacować, korygując wyniki obliczeń uzyskane $\mathrm{z}$ modelu Wu-Waldrona o połowę.

Przeprowadzone obliczenia wykazały, że sposób określania parametrów przeżywalności funkcji Weibulla i tym samym dobór przedziału średnic korzeni do ich określenia w modelu wiązkowym ma z reguły niewielki wpływ na uzyskiwane wartości przyrostu na ścinanie. W przypadku brzozy brodawkowej maksymalne różnice wartości tego parametru uzyskane przy różnych parametrach $\omega$ i $\lambda$ wynosily $11 \%$, a dla grabu zwyczajnego i sosny zwyczajnej odpowiednio 10 i $22 \%$.

\section{WNIOSKI}

Największą wytrzymałością na rozciąganie charakteryzowały się korzenie grabu zwyczajnego, a wytrzymałość korzeni brzozy brodawkowatej i sosny zwyczajnej była bardzo podobna. Otrzymane wartości parametrów funkcji przeżywalności Weibulla były małe w przypadku każdego z badanych gatunków drzew, co potwierdza dużą zmienność wytrzymałości na rozciaganie korzeni.

Stwierdzono, że sposób doboru parametrów funkcji przeżywalności Weibulla ma niewielki wpływ na wyniki obliczeń przyrostu wytrzymałości gruntu na ścinanie wzmocnionego korzeniami. W skrajnym przypadku wartości tego parametru różniły się o $22 \%$, a w większości przypadków różnica ta nie przekraczała $10 \%$.

Wartości przyrostu wytrzymałości na ścinanie uzyskane za pomocą modelu wiązkowego wykorzystującego funkcję przeżywalności (RBMw) były od około 47 do $59 \%$ mniejsze niż uzyskano z modelu Wu-Waldrona. Zatem można stwierdzić, że dla celów praktycznych do określenia wartości przyrostu wytrzymałości na ścinanie można stosować model Wu-Waldrona, korygując uzyskane nim wyniki o 50\%.

\section{PIŚMIENNICTWO}

Bischetti, G. B., Chiaradia, E. A., Simonato, T., Speziali, B., Vitali, B., Vullo, P. \& Zocco, A. (2005). Root strength and root area ratio of forest species in Lombardy (northern Italy. Plant and Soil, 278, 11-22. doi:10.1007/ s11104-005-0605-4

Bischetti, G. B., Chiaradia, E.A., Epis, T. \& Morlotti, E. (2009). Root cohesion of forest species in the Italian Alps. Plant and Soil, 324, 71-89.

Cislaghi, A., Bordoni, M., Meisina, C. \& Bischetti, G.B. (2017). Soil reinforcement provided by the root system of grapevines: Quantification and spatial variability. Ecological Engineering, 109, B, 169-185. http://dx.doi. org/10.1016/j.ecoleng.2017.04.034

Giadrossich, F., Cihen, D., Schwarz, M., Seddaiu, G., Contran, N., Lubino, M., Valdes-Rodriguez, O.A. \& Niedda, M. (2016). Modeling bio-engineering traits of Jatropha curcas L. Ecological Engineering, 89, 40-48.

Hales, T. C., Ford, C. R., Hwang, T., Vose, J. M. \& Band, L. E. (2009). Topographic and ecologic controls on root reinforcement. Journal of Geophysical Research, 114, F03013, 1-17. doi:10.1029/2008JF001168 
Zydroń, T., Gruchot, A., Czesak, K. (2018). Zastosowanie funkcji Weibulla do oceny wytrzymałości na rozciąganie korzeni wybranych gatunków drzew. Acta Sci. Pol. Architectura, 17 (4), 61-69. doi: 10.22630/ASPA.2018.17.4.41

Loades, K. W., Bengough, A. G., Bransby, M. F. \& Hallett, P. D. (2010). Planting density influence on fibrous root reinforcement of soils. Ecological Engineering, 36, $276-284$

Mao, Z., Saint-Andre, L., Genet, M., Mine, F-X., Jourdan, Ch., Rey, H., Courbaud, B. \& Stokes, A. (2012). Engineering ecological protection against landslides in diverse mountain forests: Chosing cohesion models. Ecological Engineering, 45, 55-69.

Mattia, Ch., Bischetti, G. B. \& Gentile, F. (2005). Biotechnical characteristics of root systems of typical Mediterranean species. Plant and Soil, 278, 23-32.

Pollen-Bankhead, N. \& Simon, A. (2005). Estimating the mechanical effects of riparian vegetation on stream bank stability using a fiber bundle model. Water Resources Research, 41, W07025. doi:10.1029/2004WR003801

Schwarz, M., Giadrossich, F. \& Cohen, D. (2013). Modeling root reinforcement using a root-failure Weibull survival function. Hydrology and Earth System Sciences, 17, 4367-4377.

Schwarz, M., Thormann, J. J., Zürcher, K., Feller, K. (2012). Quantifying root reinforcement in protection forests: implications for slope stability and forest management. $12^{\text {th }}$ Congress INTERPRAEVENT 2012 - Grenoble/France, 791-802.

Stokes, A., Atger, C., Bengough, A. G., Fourcaud, T. \& Sidle, R. C. (2009). Desirable plant root traits for protecting nat- ural and engineered slopes against landslides. Plant and Soil, 324 (1-2), 1-30. doi: 10.1007/s11104-009-0159-y

Vergani, C., Schwarz, M., Cohen, D., Thormann, J.J. \& Bischetii, G.B. (2014). Effects of root tensile force and diameter distribution variability on root reinforcement in the Swiss and Italian Alps. Canadian Journal of Forest Research, 44, 1426-1440. dx.doi.org/10.1139/cjfr2014-0095

Vergani, C., Schwarz, M., Soldati, M., Corda, A., Giadrossich, F., Chiaradia, E.A., Morando, P. \& Bassanelli, C. (2016). Root reinforcement dynamics in subalpine spruce forests following timber harvest: a case study in Canton Schwyz, Switzerland. Catena, 143, 275-288.

Vergani, C., Werlen, M., Conedera, M., Cohen, D. \& Schwarz, M. (2017). Investigation of root reinforcement decay after a forest fire in a Scots pine (Pinus sylvestris) protection forest. Forest Ecology and Management, 400, 339-352.

Waldron, L. J. (1977). Shear resistance of root-permeated homogeneous and stratified soil. Soil Science Society of America Journal, 41, 843-849.

$\mathrm{Wu}$, T. H. (1976). Investigation on landslides on Prince of Wales Island. Alaska Geotech Report 5. Columbus: Ohio State University.

Zydroń, T. (2014). Wpływ korzeni grabu na wytrzymałość gruntu na ścinanie. Infrastruktura i Ekologia Terenów Wiejskich, 1, 21-33.

\title{
APPLICATION OF THE WEIBULL SURVIVAL FUNCTION FOR ESTIMATION OF THE ROOT TENSILE STRENGTH OF SELECTED TREE SPECIES
}

\begin{abstract}
The study aimed at the determination of the tensile strength of the roots of common birch, European hornbeam and Scots pine and at the estimation of values of Weibull functions parameters $(\omega, \lambda)$ describing the variability of this characteristic depending on the species and the size of the root diameters. Tensile strength tests were carried out on the root samples that were placed in water at least one day prior to the test, in order to obtain their maximum saturation. The results of the tensile strength tests and Weibull function parameters values were used for the calculation of root cohesion using numerical model (fiber bundle model).

The test results revealed that the roots of the European hornbeam have statistically significantly higher tensile strength than the roots of the common birch and Scots pine. The results of the analysis showed that the values of Weibull parameters are generally small. The obtained values of the $\omega$ parameter indicate a high variability of the tensile strength characteristics of the roots of the examined plant species. It has also been shown that Weibull's method of selection of parameters can have a significant effect on the results of the root cohesion calculations. Moreover, the root cohesion values obtained by the fiber bundle model using the Weibull function were $15-55 \%$ smaller than those obtained using the classic Wu-Waldron model.
\end{abstract}

Key words: tensile strength, root reinforcement, Weibull survival function, fiber bundle model 